\title{
CONDENAÇÃO DO ABUSO DO DIREITO
}

\author{
Prof. HAROLDO VALLADÃO \\ (Catedrático das Universidades Federal e Católica \\ do Rio de Janeiro.)
}

No Anteprojeto oficial de reforma da Lei de Introdução ao Código Civil, que apresentamos com nôvo título, Lei Geral de Aplicação das Normas Jurídicas, (') estabelecemos, sob a rubrica Condenação do Abuso de Direito, o seguinte texto: "Art. 11. Não será protegido o direito que fôr ou deixar de ser exercido em prejuízo do próximo ou de modo egoísta, excessivo ou anti-social".

Acolhemos, assim, uma doutrina que veio superar o princípio romano-individualista, do "Nullus videtur dolo facere, qui jure suo utitur". Consagrou-o na linha individualista, a Introdução do Código Geral da Prússia, art. 94: "Quem exerce um direito segundo a lei não responde do dano que resulta dêsse exercício". O Código da Argentina, art. 1.071 consolidou-o, declaradamente, em nota, citando os textos romano e prussiano, e ainda o ampliou: "O exercício dum direito próprio ou o cumprimento de uma obrigação legal não pode constituir qualquer ilícito", sem a restrição que o Código prussiano estabelecera a propósito das obrigaçõese não-convencionais, L. 1. ${ }^{\circ}$ Tít. IV, art. 36, e 37, dando indenização contra quem no exercício do direito escolhe intencionalmente via que podia ser prejudicial a outro.

Os gravíssimos abusos a que abriam margem aquêles princípios, permitindo as manifestações mais desumanas do egoísmo, determinaram restrições que aparecem, no Século XIX, na América Latina, no antigo Código Civil do Peru, de 1852, estabelecendo, no art. 2.211, a do Código prussiano, que "não há obrigação de indenizar os danos causados no exercício de um direito salvo se entre os modos de $\circ$ exercer se tenha escolhido voluntàriamente $\circ$ que era prejudicial", limiłação subjetiva, e no Projeto de Código do Uruguai, de EDUARDO AZEVEDO, art. 1.600, 2. ${ }^{a}$ alínea, dispondo (fundado nas Partidas, II, Tít. 32, leis 18 e 19), no art. 1.600, que: "El que usa

1. Publicado com os respectivos Método e Orientação Geral e a Justificação de cada texto no Diário Oficial de 15-5-1964, Suplemento n.0 92 e em folheto avulso. 
de su derecho, no daña a otro, con tal que no haya exceso de su parte", ficando no Código de 1868, no art. 1.295 (hoje 1.321) com aquelas mesmas palavras, limitação mais de caráter objetivo.

Depois o Código Civil da Alemanha, de 1896, proíbe, no art. 226, o exercício dum direito com o único fim de causar dano a outrem, na tradição do Código da Prússia, fórmula ainda subjetiva, tímida.

A seguir, no século atual, o Código Civil da Suíça, 1907, adota fórmula genérica declarando, no art. $2 .^{\circ}$ do seu Título Preliminar: "o abuso manifesto do direito não é protegido pela lei", restrição objetiva que o Projeto Bustamante do Código de Cuba, 1940, repete no art. 10.

A fórmula do Código Soviético, de 1923, art. $1 .^{\circ}$, de que "os direitos civis são protegidos pela lei salvo os casos em que são exercidos em contrário ao seu destino econômico e social", excluindo - elemento moral não corresponde, pròpriamente, ao princípio do abuso do direito segundo demonstrou RENÉ DAVID, afirmando, ainda, que teria ali caído em desuso (Le Droit Sovietique, I, 1954, pp. $133-5$ e 251 ).

O texto correspondente das Bases da Legislação Soviética, citadas, de 1960, art. 5. ${ }^{\circ}$, diz apenas: "Os direitos civis são protegidos pela lei", enumerando as vias asseguradoras dos mesmos: tribunais, arbitragem do Estado ou dos juízes arbitrais, tribunais de honra, processo administrativo. Ali $\circ$ art. $4 .^{\circ}$ dá à legislação civil a finalidade de incrementar o sistema socialista, de dar base material-técnica ao comunismo e satisfação crescente às necessidades econômicas e espirituais dos cidadãos.

Mas, ainda na América Latina, o nôvo Código Civil do Peru, de 1936, dá um passo adiante ao prescrever no art. III de seu Título preliminar que "A lei não ampara o abuso do direito" suprimindo o restritivo "manifesto" ao têrmo "abuso" (veja-se o importante trabalho justificativo do Sr. JUAN JOSÉ CALLE nas Actas... da Com. Reformad. del Código... 6. Fascic., pp. 190/205).

O Código Civil do Egito de 1948 após proclamar no art. 4. ${ }^{\circ}$ "não ser quem exerce seus direitos responsável por prejuízos conseqüentes", condena no art. 5. tal exercício "se feito com o intuito único de lesar outrem, se o benefício desejado é desproporcional ao prejuízo causado a outra pessoa, se tal benefício é ilegal" unindo o lado subjetivo ao objetivo, tìmidamente. 
Nenhum progresso, porém, representou o texto aprovado pela Comissão de Reforma do Código (Travaux, Année 1950-1951, pp. $14 / 15,19 / 20$ e 22/25) para ser incluído no Título Preliminar, art. 31 (Trav. cit., p. 26) negando proteção legal a "todo ato ou fato que excede manifestamente pelo fim visado pelo seu autor, por seu objeto ou pelas circunstâncias em que interveio, o exercício normal de um direito, excluídos os direitos que por sua natureza ou por lei são discricionários". Foi até um regresso, pois justamente os direitos ressalvados é que permitem os maiores abusos no seu exercício. Predominou na discussão e no texto um espírito conservador, individualista mesmo (Travaux, p. 15 rapport de NIBOYET ET HOUIN), de reação às novas idéias, ali já expostas e pregadas no início do Século por SALLEILES (Obligations dans le Projet du Code Civil allemand, 1901, nota I, pp. 370/3 e texto proposto na Sociedade de Estudos Legislativos, 1905, Bulletin, IV), CHAUMONT, (Revue Trim. Dr. Civil, 1905) e JOSSERAND (Abus des Droits, 1905).

Convém comparar com o texto de SALLEILES, mais enérgico e sem ressalvas (in ALFREDO VALLADÃO, O Abuso do Direito, Jornal de Comércio de 7/2/1912 e Rev. Trib., S. Paulo, v. 334, p. 26).

No Brasil, nem nos Projetos anteriores nem no Projeto BEVILÁQUA aparece a proibição do abuso do direito, mesmo na forma acanhada do Código Alemão.

Na sua Consolidação, CARLOS DE CARVALHO, 1899, mandava no art. 1.029 indenizar se houve excesso no exercício do direito, fundando-se na Orden. L. 4, Tít. n. ${ }^{\circ} 2$ que deixava o Juiz decidir, consideradas as circunstâncias, se o desfôrço fôra ou não incontinenti ou logo.

Era um passo incipiente, mas quem levantou o problema, no Brasil, foi o Ministro ALFREDO VALLADÃO, quando da discussão, no Senado, do Projeto do Código Civil, em artigo no Jornal do Comércio de 4 de fevereiro de 1912, com o título: O Abuso do Direito, e que assim se iniciava: "Há uma disposição que precisa entrar para o Código Civil: é a que entende com o abuso do direito. Sem ela, o Código estará inferior à sua época. E, por isto, esperamos que o Senado volte para o assunto a sua preciosa atenção". Continuava: "O exercício do direito também constitui uma injúria sempre que êle se pratique com abuso manifesto", e, ainda, após referir os Códigos Alemão e Suíço, citar CHAUMOUNT, SALLEILLES, JOSSERAND, ÁVILA LIMA e GUILHERME ALVES MOREIRA, e responder às críticas formais e de fundo à teoria do abuso do direito feitas por PLANIOL e ESMEIN e dos tradicionalistas, justificou-a partindo do princípio da inexis- 
rência de direitos absolutos e de que a própria liberdade não é ilimirada para proclamar: "Em suma: emanação da liberdade, os direitos não podem ser exercidos com o abuso que não se permite à própria liberdade". E pôde concluir: "A nosso ver, o abuso do direito caracteriza-se pela anormalidade de seu exercício, pelo seu exercício antisocial. E esta há de ser apreciada objetivamente, embora, em muitos casos, a apreciação objetiva envolva a necessidade de se conhecer o elemento psicológico" (Rev. Trib., S. P. 334-38).

Todavia não foi ouvido o apêlo de ALFREDO VALLADÃO em 1912, e o Código Civil brasileiro de 1916 não condenou o abuso do direitio.

Promulgado o Código, CLÓVIS BEVILÁQUA (Cód. Civil, Observ. ao texto) procurou ali um lugar para a doutrina do abuso do direito, em interpretação, data venia, forçada, das últimas palavras do art. 160, I ao dispor que: "Não constituem atos ilícitos: I. Os praticados em legítima defesa ou no exercício regular de um direito reconhecido".

Note-se, desde logo, que a expressão "no exercício regular de um direito reconhecido" não constava de nenhum Projeto, tendo o Projeto BEVILÁQUA ali previsto, art. 172, apenas a justificativa da legítima defesa: "Não constituem atos ilícitos os praticados em legítima defesa". . Aquela expressão aparece na redação final do Projeto da Comissão Revisora, sem constar de qualquer das Atas sua apresentação e justificação. Na $11 .^{a}$ reunião o Professor LACERDA DE ALMEIDA propôs que os artigos 172 e 173 do Projeto Beviláqua passassem para o capítulo dos Atos llícitos (Trabalhos de Elaboração. Cód. Civ. Br., I, p. 372); na $41 .^{\text {a }}$ reunião alterou-se o art. 172 do Frojeto Beviláqua só para melhor caracterizar a legítima defesa (Trab. cir., 1, p. 565) e na $3 .^{a}$ reunião da 2.a Série, com a presença de CLÓVIS BEVILÁQUA, não se tocou no artigo (Trab. cit., I, p. 629). No entanto, no Projeto Revisto, redação final, aparece o art. 181, substitutivo do art. 172 de BEVILÁQUA com o acréscimo, sem qualquer emenda ou modificação, "ou no exercício regular de um direito reconhecido" (Trab. cit., I, p. 684)) que afinal prevaleceu, sem qualquer debate, na Comissão Especial, da Câmara ou do Senado.

Para incluir no art. 160, I, a condenação do abuso do direito teve CLÓVIS BEVILÁQUA de, acompanhando MELLO FRANCO, argumentar a contrario sensu, asseverando que o ato praticado no exercício não regular de um direito é ilícito...

Mas o problema de abuso do direito não podia, já em 1916, segundo se viu, ser colocado, assim clandestinamente, no Código, 
e o exercício não regular do direito visa a algum defeito legal do mesmo exercício e não o seu exercício ou a falta do seu exercício, de modo egoísta, excessivo ou anti-social, na humanista doutrina do abuso do direito que foi caracterizada no art. 11 do Anteprojeto.

Note-se que ali foi acentuado, também, 0 abuso pela omissão do titular do direito, apesar de solicitado, p. ex., do proprietário do imóvel urbano que o deixa fechado ou do imóvel rural que não o explora e se recusa a arrendá-lo ou a loteá-lo, apesar de haver candidaíos ao arrendamento ou à compra.

E, por isto, até hoje não se encontram decisões de nosso tribunais consagrando a doutrina do abuso do direito, com fundamento no art. 160, l, fine, dando indenização pelo simples exercício irregular do direito; buscam, sempre, amparo no dolo ou na intenção maléfica do autor do ato (CARV. SANTOS, op. cit., II, pp. 350 e segs.; OSCAR DA CUNHA, O Dolo e o Dir. Judiciário, p. 241, fine, etc.).

$E$, por isto, na órbita processual onde são tão freqüentes os abusos de direito, foi mister que o Cód. de Proc. Civil, de 1939, o previsse de forma expressa, art. $3 .^{\circ}$.

Depois, o Anteprojeto do Código de Obrigaçõees, de 1945, art. 156 previu-o como: excesso no exercício do direito aos limites do interêsse por êste protegido ou dos decorrentes da boa-fé, seguindo o art. 155 do Código Polonês das Obrigações, de 1935.

No séntido do texto e, mesmo além, escrevemos, em 1962, "necessitamos sentir todos que vivem o Brasil e o Mundo a época do social, que está acima do econômico, que tem base jurídico-moral e religiosa, que significa compreender a vida em função do bem de nossos semelhantes, que se orienta pelo altruísmo. O lema atual não é usar $\circ$ meu direito sem ofender $\circ$ alheio, mas usá-lo visando, ainda, o bem dos outros. Não é usar da liberdade sem prejudicar a de outrem mas utilizá-la para ajudar a dos nossos semeIhantes" (Desenvolvimento Econômico Social em Forma Jurídica, p. $16,1962)$.

Está, pois, o texto sincronizado com a disposição anterior do Anteprojeto, sôbre "Interpretação": "Art. 9.० A aplicação das normas jurídicas se fará sob a inspiração do bem comum, da justiça social e da eqüidade".

Em verdade, a "Justiça Social", imperativo supremo de nossos tempos, é a justiça distributiva baseada na eqüidade e na caridade, valôres cristãos, não sòmente morais, mas preceitos positivos, inde- 
clináveis, verdadeiros imperativos da justiça superior, no dizer de SANTO TOMÁS.

Destarte, tivemos de adotar no século XX outra filosofia, profundamente cristã, a filosofia do "ama a teu próximo como a ti mesmo", (não do "como ele te ama", da justiça comutativa, da guerra fria). É a filosofia do "help for life" ou melhor da "community for life" (superado o "struggle for life", materialista), da ajuda para a vida com a cooperação fraternal de todos para a sobrevivência e a felicidade de todos.

Êsse princípio supremo de justiça social, que é a condenação do abuso do direito, evidentemente não pode ficar apenas num dos vários Códigos ou das várias Leis, existentes no país.

E fundamental, básico, deveria estar na própria Constituição.

No plano da legislação ordinária o seu lugar é no princípio de tôdas as leis, na lei Preliminar, na lei Introdutória, na Lei Geral de Aplicação das Normas Jurídicas. 